\title{
Localisation of atrial natriuretic peptide immunoreactivity in the ventricular myocardium and conduction system of the human fetal and adult heart
}

\author{
JOHN WHARTON, ROBERT H ANDERSON, * DAVID SPRINGALL, \\ ROBERT F POWER, MARLENE ROSE, $\dagger$ AUDREY SMITH, $\ddagger$ ROSARIO ESPEJO, \\ ASGHAR KHAGHANI, $\dagger$ JOHN WALLWORK,§ MAGDI H YACOUB, $\dagger$ \\ JULIA M POLAK
}

\begin{abstract}
From the Department of Histochemistry, Royal Postgraduate Medical School, London; ${ }^{\star}$ Department of Paediatrics, the Cardiothoracic Institute, London; †Cardiothoracic Unit, Harefield Hospital, Harefield, Middlesex; $\ddagger$ Institute of Child Health, University of Liverpool, Liverpool; §Transplant Unit, Papworth Hospital, Papworth Everard, Cambridgeshire
\end{abstract}

SUMMARY Atrial natriuretic peptide immunoreactivity was found in ventricular and atrial tissues with specific antisera raised to the amino and carboxy terminal regions of the precursor molecule. In 13 developing human hearts (7-24 weeks' gestation) the immunoreactivity was concentrated in the atrial myocardium and ventricular conduction system but it was also detected in the early fetal ventricular myocardium. Immunoreactivity in five normal adults was largely confined to the atrial myocardium although it was also found in the ventricular conduction tissues of hearts removed from 10 patients who were undergoing cardiac transplantation. The ventricular conduction system is an extra-atrial site for the synthesis of atrial natriuretic peptide. In the failing heart this synthesis may be further supplemented by expression of the gene in the ventricular myocardium.

It is possible that ventricular production of the peptide contributes to the raised circulating concentrations of atrial natriuretic peptide immunoreactivity found in severe congestive heart disease, particularly in patients with dilated cardiomyopathy.

Cardiac expression of the gene for atrial natriuretic peptide was originally thought to occur specifically in the atrium because immunoreactivity was localised in atrial myocytes of several mammals including $\operatorname{man}^{12}$ and stored as the precursor molecule in secretory vesicles. $^{3-5}$ It has since been established, however, that both atrial natriuretic peptide messenger ribonucleic acid and immunoreactivity are also present in ventricular tissues ${ }^{6-8}$ and cultures of ventricular myocytes. ${ }^{5910}$ Furthermore, the ventricular expression of the gene changes during development; the concentration of atrial natriuretic peptide transcripts (copies of messenger ribonucleic acid) and immunoreactivity was greater in fetal tissues than in adult tissues. ${ }^{711} 12$ The localisation of ventricular immunoreactivity in the human heart has still to be estab-

Requests for reprints to Dr John Wharton, Department of Histochemistry, Royal Postgraduate Medical School, Du Cane Road, London W12 ONN.

Accepted for publication 17 May 1988 lished, but the subendocardial distribution of immunostaining in rat ${ }^{13-15}$ and pig ventricles ${ }^{16}$ has led to the suggestion that the immunoreactivity may be associated with the ventricular conduction system.

In patients with severe congestive heart disease ventricular expression of the atrial natriuretic peptide gene is augmented ${ }^{17}$ and circulating concentrations of immunoreactivity are increased. ${ }^{18-20}$ But it is not known whether the ventricular production of peptide is widespread or localised ${ }^{21}$ or whether it is a feature common to the diseased heart or is associated with specific conditions. With these questions in mind, we used immunocytochemical techniques to investigate the occurrence of atrial natriuretic peptide immunoreactivity in the human conduction system and ventricular myocardium and to examine whether the pattern of distribution changes during cardiac development and disease. We also compared the localisation of ventricular immunoreactivity with that of the general neuroendocrine marker protein gene product $9 \cdot 5^{22}$ after initial findings indicated 
possible similarities in their distribution patterns of the two substances in conduction tissues.

\section{Patients and methods}

Three different antisera (code no XA6, AT7, and AG9) were raised to specific regions of the precursor molecule of human atrial natriuretic peptide by immunising rabbits with pure synthetic human proatrial natriuretic peptide 1-16 (cardiodilatin 1-16, Peninsula Laboratories Europe; antiserum XA6), and atrial natriuretic peptide $\operatorname{Tyr}^{41} 1-40$ amino terminal fragments (cardiodilatin $\mathrm{Tyr}^{41}$ 1-40; antiserum AT7), and the pro-atrial natriuretic peptide 99-126 carboxy terminal fragment ( $\alpha$-atrial natriuretic peptide 1-28; antiserum AG9). We injected the peptide fragments that were conjugated to bovine serum albumin with glutaraldehyde or unconjugated as previously described. ${ }^{323}$ We also used additional antiserum (code no 1648) directed against human protein gene product 9.5 (Ultraclone, Cambridge) that has been previously characterised. ${ }^{22}$

Tissues were obtained from 13 human fetuses after spontaneous or legal abortion (7-24 weeks' gestation) and at necropsy from five adults without cardiac or pulmonary complications (3-15 hour delay after death (table)). Samples of atrial and ventricular septal and free walls were also obtained during transplantation surgery from 10 patients with heart and lung diseases (table). The tissues were dissected so that the ventricular conduction system could be

Table Clinical features of patients whose hearts were examined for atrial natriuretic peptide immunoreactivity

\begin{tabular}{|c|c|c|c|c|c|}
\hline $\begin{array}{l}\text { Patient } \\
\text { No }\end{array}$ & Sex & $\begin{array}{l}\text { Age } \\
(y r)\end{array}$ & $\begin{array}{l}H \text { or } \\
H / L\end{array}$ & $\begin{array}{l}\text { Diagnosis or cause of } \\
\text { death }\end{array}$ & NYHA \\
\hline $\begin{array}{l}1 \\
2 \\
3 \\
4 \\
5\end{array}$ & $\begin{array}{l}\mathbf{M} \\
\mathbf{F} \\
\mathbf{F} \\
\mathbf{F} \\
\mathbf{F}\end{array}$ & $\begin{array}{l}31 \\
60 \\
75 \\
24 \\
65\end{array}$ & Necrop & $\begin{array}{l}\text { Posy specimens } \\
\text { Road traffic accident } \\
\text { Hodgkin's disease } \\
\text { Septicaemia } \\
\text { Asphyxia (hanging) } \\
\text { Glucagonoma } \\
\text { splantation recipients }\end{array}$ & \\
\hline 1 & $\mathbf{M}$ & 17 & $\mathbf{H} / \mathbf{L}$ & $\begin{array}{l}\text { splantation reciptents } \\
\text { Failure of previous lung } \\
\text { transplant in patient } \\
\text { with cystic fibrosis }\end{array}$ & IV* \\
\hline $\begin{array}{l}2 \\
3 \\
4 \\
5 \\
6\end{array}$ & $\begin{array}{l}\mathbf{F} \\
\mathbf{F} \\
\mathbf{M} \\
\mathbf{M} \\
\mathbf{M}\end{array}$ & $\begin{array}{l}2 \\
17 \text { mnth } \\
59 \\
59 \\
28\end{array}$ & $\begin{array}{l}\mathbf{H} / \mathbf{L} \\
\mathbf{H} \\
\mathbf{H} \\
\mathbf{H} \\
\mathbf{H}\end{array}$ & $\begin{array}{l}\text { Tricuspid atresia } \\
\text { Dilated cardiomyopathy } \\
\text { Ischaemic heart disease } \\
\text { Dilated cardiomyopathy } \\
\text { Adriamycin } \\
\text { cardiomyopathy }\end{array}$ & $\begin{array}{l}\text { III } \\
\text { IV } \\
\text { III } \\
\text { III } \\
\text { III }\end{array}$ \\
\hline $\begin{array}{l}7 \\
8\end{array}$ & $\stackrel{\mathbf{M}}{\mathbf{F}}$ & $\begin{array}{r}6 \\
28\end{array}$ & $\underset{\mathbf{H} / \mathbf{L}}{\mathbf{H} / \mathbf{L}}$ & $\begin{array}{l}\text { Eisenmenger's syndrome } \\
\text { Idiopathic pulmonary } \\
\text { haemosiderosis }\end{array}$ & IV \\
\hline $\begin{array}{r}9 \\
10\end{array}$ & $\underset{\mathbf{F}}{\mathbf{M}}$ & $\begin{array}{l}29 \\
21\end{array}$ & $\begin{array}{l}\mathbf{H} / \mathbf{L} \\
\mathbf{H} / \mathbf{L}\end{array}$ & $\begin{array}{l}\text { Sarcoidosis } \\
\text { Cystic fibrosis }\end{array}$ & $\underset{\mathbf{I V}}{\mathbf{I V}}$ \\
\hline
\end{tabular}

*Grade of lung disease.

Predominantly affecting the right side.

$H$, heart transplant; $H / L$, heart and lung transplant; NYHA, New York Heart Association. examined by sectioning mainly in the frontal plane (at right angles to the atrioventricular septal junc-: tion $\left.^{24}\right)$. The collection of the tissues used in this study conformed to the ethical standards of the institutiong in which they were obtained.

Tissues were fixed by immersion for 16-24 hours? at $4^{\circ} \mathrm{C}$ in a modified Bouin's solution containing $85 \mathrm{ml}$ of $2 \%(\mathrm{w} / \mathrm{v})$ paraformaldehyde in $0.1 \mathrm{~mol} / \mathrm{w}$ phosphate buffer (pH 7.2) and $15 \mathrm{ml}$ of saturated. picric acid per $100 \mathrm{ml}$ of fixative. We rinsed the tissues in several changes of phosphate buffered $\vec{\omega}$ saline $(0.01 \mathrm{~mol} / 1 \mathrm{pH} 7 \cdot 2)$ containing $15 \%$ sucrose and $0.1 \%$ sodium azide and then processed them fo cryostat sectioning and indirect immunofluorescenco staining. Briefly, sections ( $15 \mu \mathrm{m}$ thick) were cut on a Bright cryostat at $-25^{\circ} \mathrm{C}$, mounted on poly-L-lysine coated slides, and air dried for an hour at room temperature. They were then immersed in bufferec saline solution containing $0.2 \%$ Triton $X-100$ for 30 minutes, rinsed, stained with pontamine sky blu尺 (BDH chemicals, UK), and rinsed again. Sections were subsequently incubated in primary antisera (diluted 1:200-1:3200) for $16-24$ hours at $4^{\circ} \mathrm{C}$, rinsed in buffered saline, and then incubated with fluorese cein isothiocyanate labelled sheep anti-rabbit $\mathbf{I g} G^{\circ}$ (diluted 1:100; Wellcome Diagnostics, UK). WE mounted the preparations in glycerol mixed in equaf parts with buffered saline and examined them with $\bar{D}$ microscope (Olympus AH-2) equipped for epio illumination.

To facilitate the identification of conduction tis $\overrightarrow{0}$ sues we cut additional sections for haematoxylin an $\$$ eosin staining and some immunofluorescence preparations were also stained after photography? Blocks containing ventricular conduction tissues were cut sequentially so that the conduction system could be followed from the atrioventricular node through to the distal bundle branches. In contro $\mathbb{B}$. experiments, we saw $n$ r immunostaining for atriad natriuretic peptide whe: the primary antisera were preabsorbed with their respective antigens $\left(10^{-5} \mathrm{O}\right.$ $10^{-6} \mathrm{~mol} / \mathrm{l}$ ) for 24 hours at $4^{\circ} \mathrm{C}$. Immunostaining fo protein gene product 9.5 was abolished by preabsorption of the antiserum with the naturaf human antigen $\left(2 \times 10^{-7} \mathrm{~mol} / 1\right)$. There was no cros 8 reactivity between the amino (XA6, AT7) or carboxty terminal (AG9) directed 2ntisera and the carboxy ( $\alpha$ 岕 atrial natriuretic peptide) and the amino terminat (cardiodilatin) peptide sequences respectively. The antisera also showed no cross reactivity with know cardiovascular neuropeptides.

\section{Results}

The distribution of immunostaining for all thre antisera raised to the amino and carboxy terminat 
sequences of human pro-atrial natriuretic peptide 1126 was identical in both fetal and adult heart tissues. The immunoreaction was generally more intense with the antiserum (AT7) raised to the larger amino terminal cardiodilatin fragment (atrial natriuretic peptide $\operatorname{Tyr}^{41} 1-40$ ) but a characteristic perinuclear concentration of immunoreactivity was seen with all three antisera. There was strong immunoreactivity in the fetal atrial myocardium and some immunostaining of the ventricular myocardium. Immunostaining of the ventricular walls was concentrated in the subendocardial myocardium and least extensive in the epicardial regions. In all the fetal hearts immunoreactivity occurred in the subendocardial left and right bundle branches (fig 1). Some cells in the penetrating and branching bundle were also immunoreactive. The intensity of the immunostaining in the ventricular myocardium was less than in other regions of the fetal heart and when increasing dilutions of the primary antisera were tested it disappeared at lower dilutions than in the conduction system and atrial myocardium. The ventricular myocardial immunoreaction was most prominent in the fetal heart at 7-12 weeks' gestation whereas by 18-24 weeks it seemed to be mainly localised in subendocardial conducting cells. In contrast with the ventricular conduction system, cells in the sinus and atrioventricular nodes showed no immunostaining (fig 2).

Unlike the fetal heart, there seemed to be little expression of the atrial natriuretic peptide gene in ventricular conduction tissues obtained at necropsy from patients without cardiac or pulmonary complications. These tissues showed either no reaction or weak immunostaining that was confined to conducting bundle branches. Though the delay between death and obtaining the tissues was short (3-15 hours), in at least some of these cases it is possible that the apparent lack of immunostaining reflects a postmortem loss of immunoreactivity. In contrast,

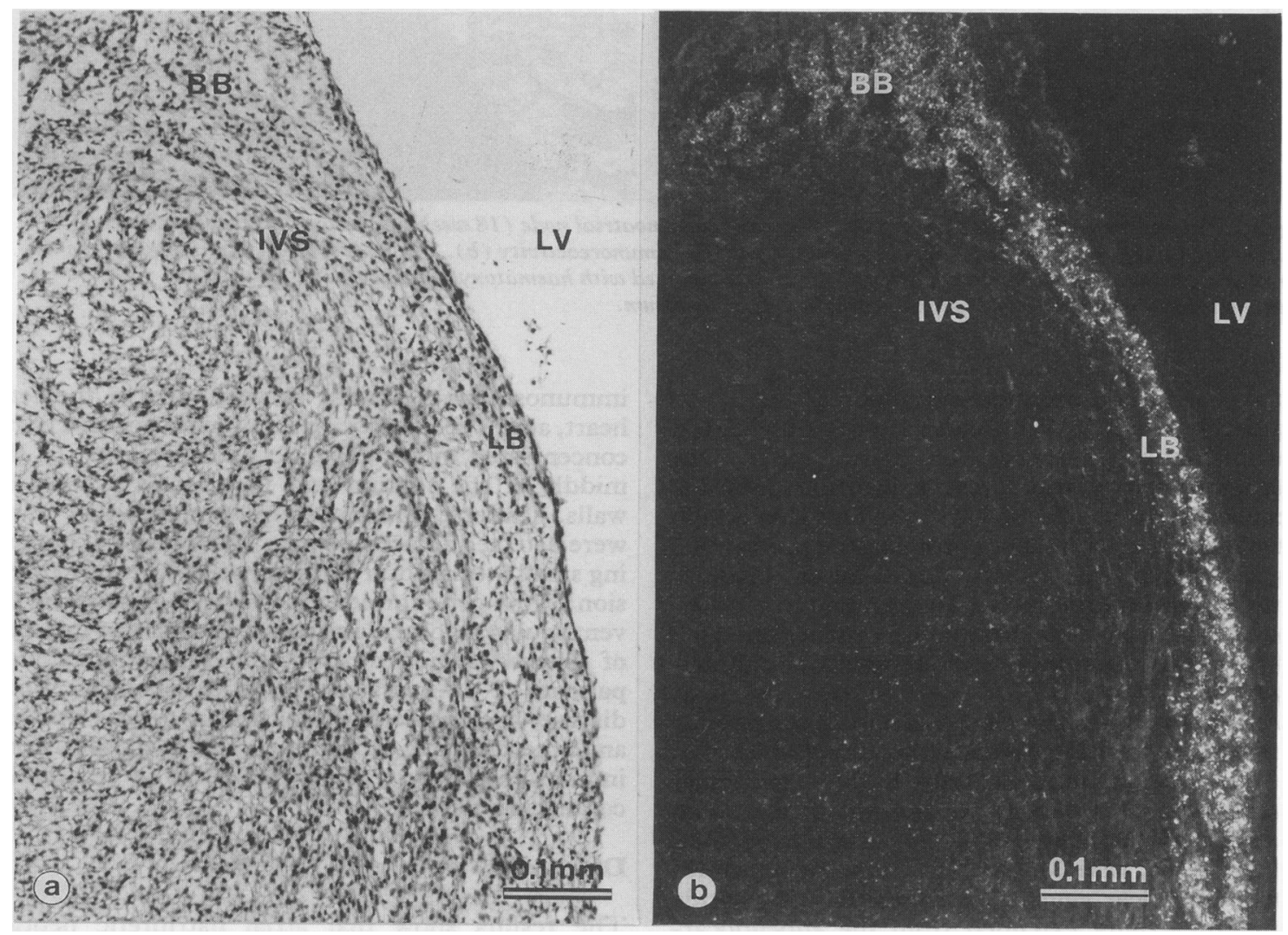

Fig 1 Photomicrographs of adjacent longitudinal sections through the interventricular septum (IVS) of a 9 week fetal heart showing atrial natriuretic peptide immunoreactivity (b) in the branching bundle (BB) and left bundle (LB). Haematoxylin and eosin (a) and immunofuorescent staining (b). LV, left ventricle. 

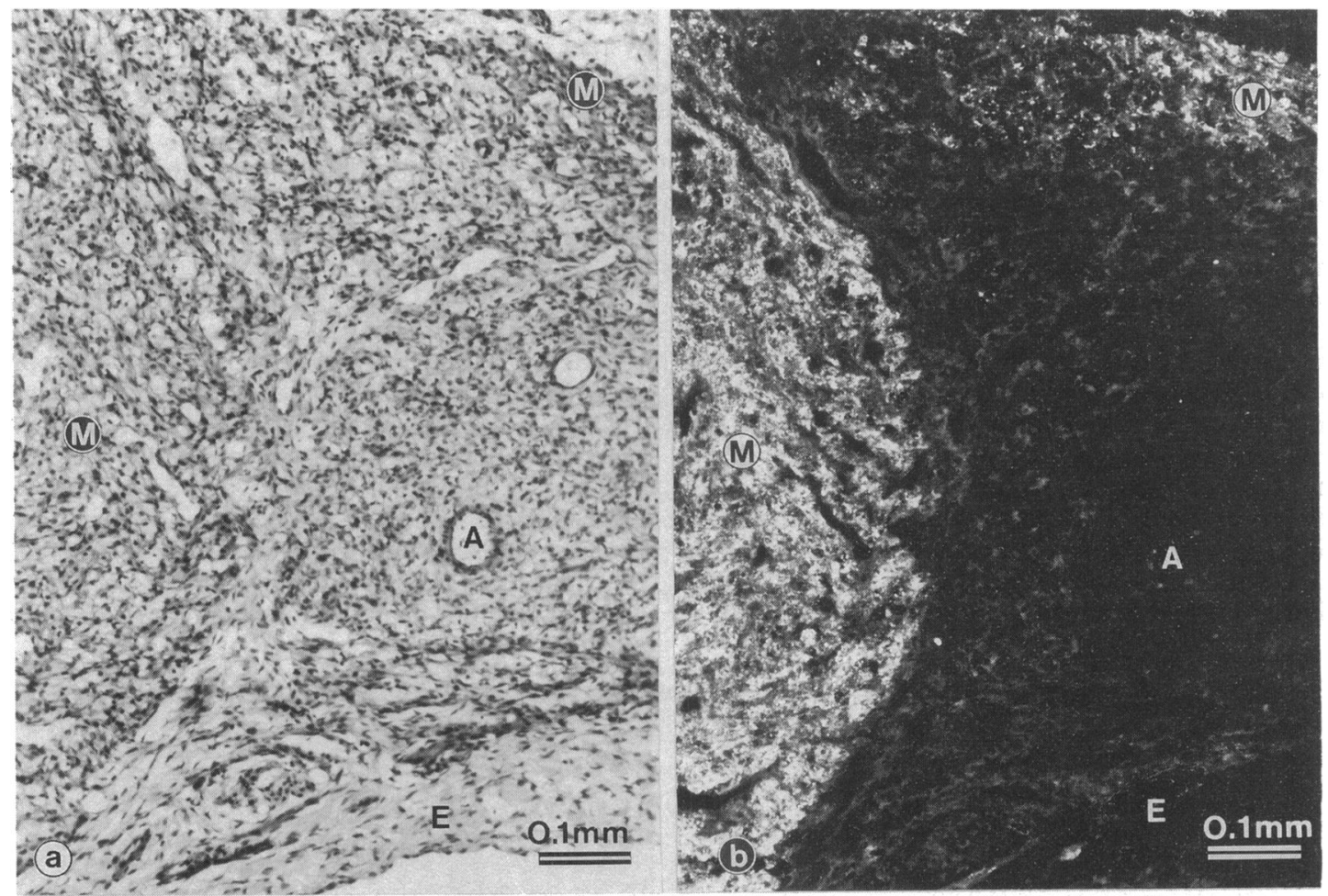

Fig 2 Photomicrographs of the same section of human fetal sinoatrial node (18 weeks' gestation) and adjacent atrial myocardium $(M)$ showing intense atrial natriuretic peptide immunoreactivity (b). The node is clearly distinct from the atrial myocardium and has a central artery $(A)$. Section stained with haematoxylin and eosin $(a)$ after the immunostained preparation (b) was photographed. E, epicardium.

atrial natriuretic peptide immunoreactivity was regularly shown in ventricular tissues obtained at transplantation surgery. In these cases, the immunoreactivity was present in subendocardial elements of the conduction system. This localisation often coincided with that of protein gene product 9.5 (fig 3) which was usually localised in intrinsic neurones and cardiac nerves (rather than in conduction tissues) in the fetal heart and in tissues obtained at necropsy from patients without cardiac or pulmonary complications.

As well as finding that the atrial natriuretic peptide gene was expressed in ventricular conduction tissues, we also saw immunoreactivity in the ventricular myocardium of a patient (17 months of age) with dilated cardiomyopathy and end stage ventricular failure (table, case 3). Sheets of myocardial fibres with perinuclear rings of atrial natriuretic peptide immunoreactivity extended from the subendocardium deep into the myocardium of the interventricular septum, left and right ventricle walls, and papillary muscles (figs 4 and 5). We saw a gradient of immunostaining, similar to that seen in the fetal heart, across the ventricular wall, with positive fibres concentrated in the subendocardial regions. In the middle of the septum and in the free ventricular walls, scattered immunoreactive myocardial fibres were detected adjacent to interstitial regions containing small intramyocardial arteries. While the expression of the gene for atrial natriuretic peptide in the ventricular myocardium was prominent in this case $\frac{?}{0}$ of dilated cardiomyopathy it was not apparent in patients (2-59 years of age) with ischaemic heart $N$ disease, haemosiderosis, sarcoidosis, cystic fibrosis, $N$ and other forms of cardiomyopathy; in these patients $N$ immunoreactivity was only detected in ventricular ${ }_{\sigma}^{\omega}$ conduction tissues.

\section{Discussion}

The results show that atrial natriuretic peptide $\frac{0}{0}$ immunoreactivity occurs in the ventricles of the human heart both during fetal development and in $\frac{\mathbb{P}}{\mathbb{P}}$ patients with diseases that eventually led to cardiac 


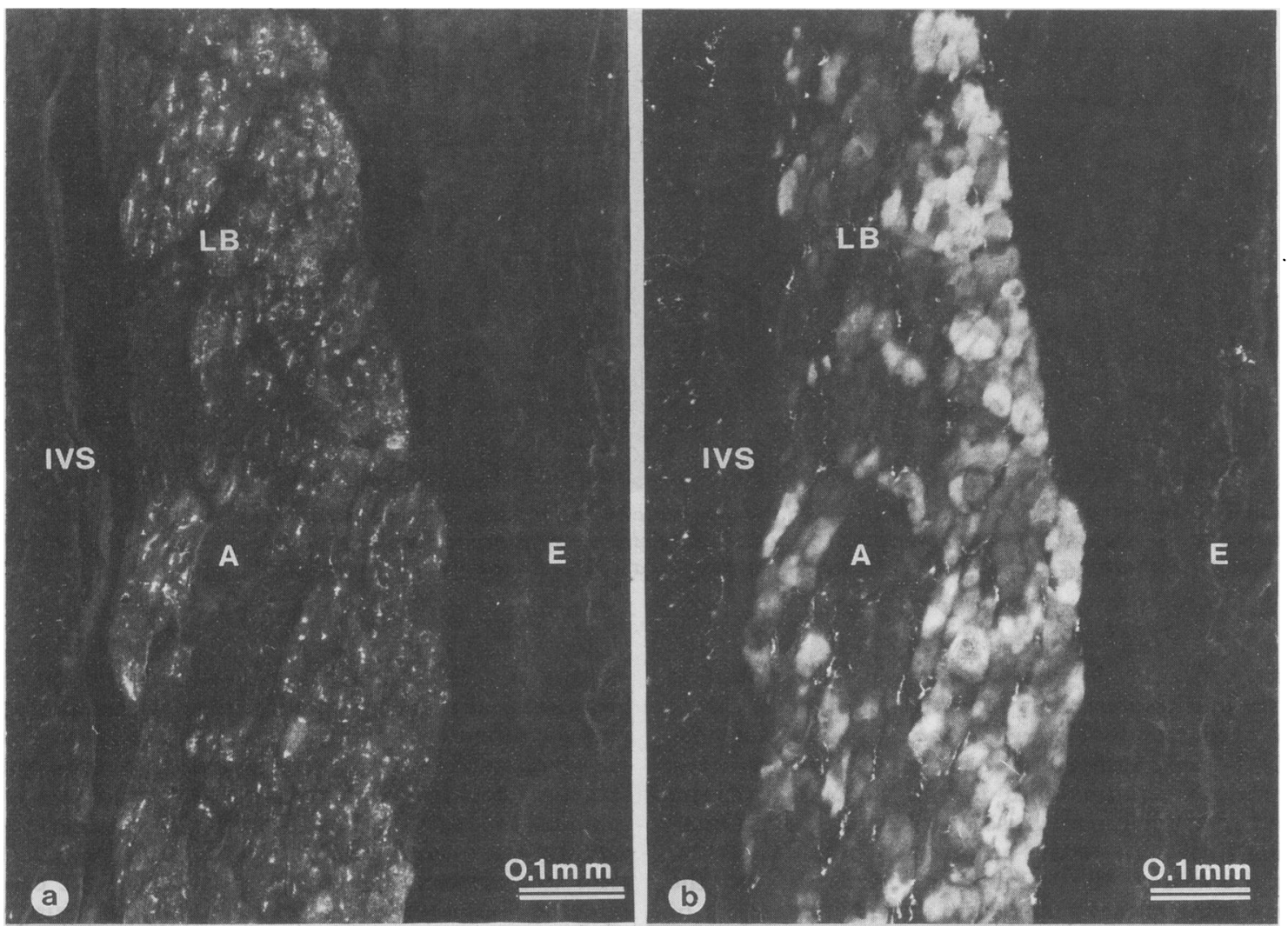

Fig 3 Photomicrographs of adjacent sections of the interventricular septum (IVS) in an adult heart obtained at transplantation from a patient with cystic fibrosis (table, case no 10) showing the presence of both atrial natriuretic peptide (a) and protein gene product 9.5 immunoreactivity (b) in cells of the left bundle (LB) at the top of the interventricular septum. Protein gene product 9.5 immunoreactivity is also present in scattered nerve fibres in the bundle. $E$, endocardium of left ventricle; $A$, arteriole.

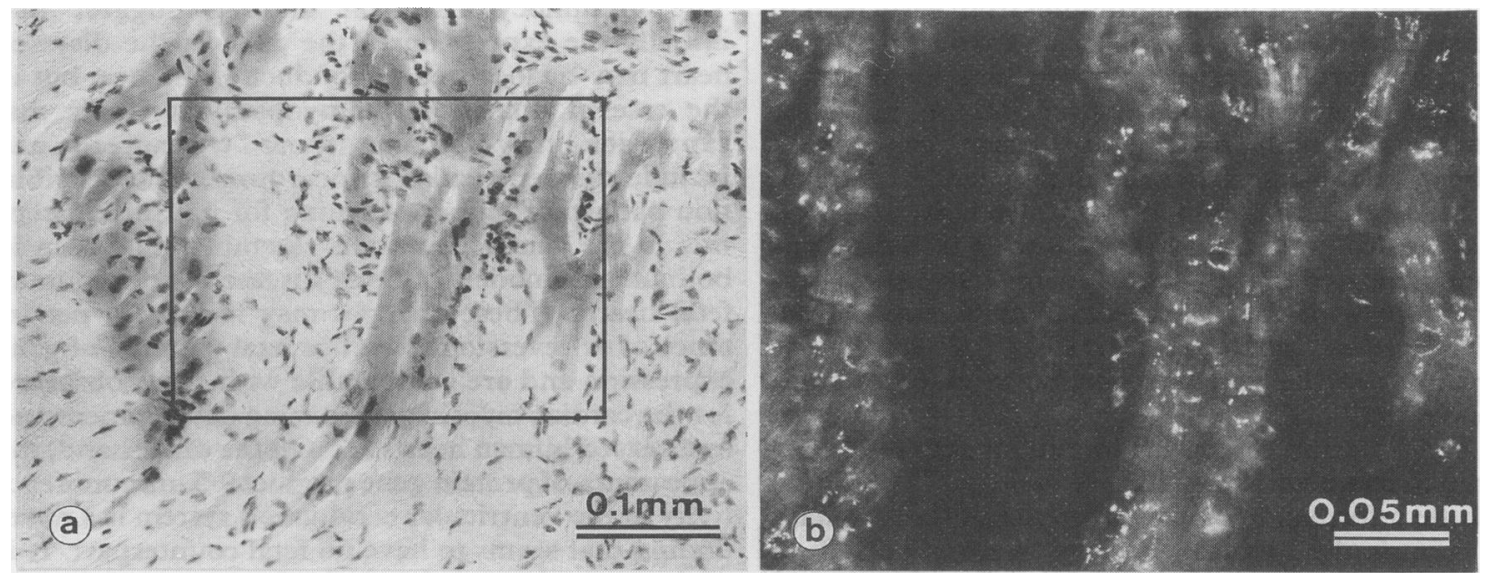

Fig 4 Photomicrographs of the same section of left ventricular posterior wall from a transplant patient (table, case no 3) with dilated cardiomyopathy. The photomicrographs are shown at two magnifications and show subendocardial myocardial fibres with perinuclear rings of atrial natriuretic peptide immunoreactivity (b) dispersed in a dense fibrous tissue. Haematoxylin and eosin (a). 


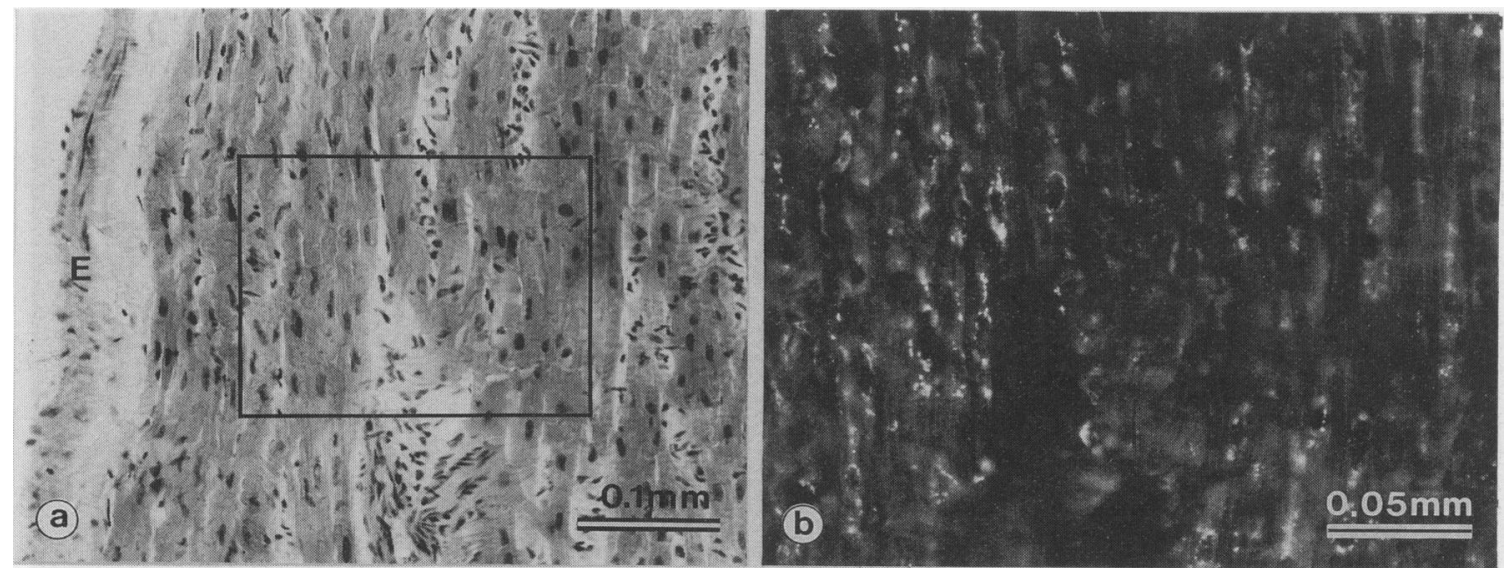

Fig 5 Photomicrographs of the same section of left ventricular papillary muscle from a transplant patient (case no 3 ) shown at two magnifications and showing the presence of atrial natriuretic peptide immunoreactivity (b) in a continuous sheet of parallel myocardial fibres. Haematoxylin and eosin (a). E, endocardium of left ventricle.

transplantation. It seems likely that the distribution of the immunoreactivity reported here reflects that of the precursor molecule (pro-atrial natriuretic peptide 1-126), rather than the smaller $\alpha$-natriuretic peptide or cardiodilatin forms, since the antisera used specifically recognised carboxy and amino terminals of pro-atrial natriuretic peptide 1-126. Furthermore, the precursor molecule is the predominant molecular form found in extracts of both ventricular and atrial tissues. ${ }^{51012}$ The immunocytochemical findings indicate that there are developmental changes in the regulation of the expression of the atrial natriuretic peptide gene in human ventricular tissues. The decline in the extent of the ventricular immunostaining from early fetal to infant and adult life is similar to that reported for atrial natriuretic peptide immunoreactivity and messenger ribonucleic acid concentrations in tissue extracts of both rat $^{71}$ and human ventricles. ${ }^{12}$ Though the mechanisms regulating gene expression in the ventricles are unknown it has been proposed that the decline in transcription during fetal development is related to the haemodynamic changes occurring during the transition from fetal to extra-uterine life together with the sensitivity of ventricular myocytes to the perinatal decline in glucocorticoid concentrations. ${ }^{25}$

Atrial natriuretic peptide immunoreactivity is confined to characteristic secretory vesicles, ${ }^{124}$ but there is little information on the occurence of such vesicles in ventricular tissues. Vesicles were reported in human $^{26}$ and pig conduction tissues ${ }^{16}$ and scattered vesicles were identified in hamster and rat ventricular myocytes ${ }^{727}$ and these were immunoreactive. ${ }^{5}$ The paucity of vesicles in ventricular cells has led to the proposal that there are two tissue specific secretory pathways for atrial natriuretic peptide in the heart. In $\vec{\varnothing}$ the atria, natriuretic peptide is stored in numerous $\infty$ secretory vesicles whereas ventricular myocytes are thought to lack vesicles and secrete the peptide? rapidly after synthesis. ${ }^{1027}$ None the less, both immunoreactivity and secretory vesicles were considerably increased in the ventricular myocardium of $\frac{\circ}{\circ}$ hamsters with cardiomyopathy and severe congestive $\stackrel{\varrho}{\rightarrow}$ heart failure. ${ }^{27}$ The ventricular expression of the $\overrightarrow{\overrightarrow{0}}$ natriuretic peptide gene is also stimulated in the hypertrophied and volume overloaded rat heart ${ }^{28} 29$ and in patients with severe congestive heart disease. ${ }^{17}$ The immunocytochemical findings suggest that $\frac{\vec{\sigma}}{\sigma}$ initially the expression of the gene in the diseased heart may be localised to conduction tissues, but in $\vec{\sigma}$ the case of dilated cardiomyopathy it seems that 3 . expression may become more widespread and $\delta$ include the ventricular myocardium. The distribution pattern of immunostaining for natriuretic pep- 0 tide in the ventricular walls resembles that seen in both animal models of heart disease $e^{29}$ and in human $\frac{D}{O}$ fetal hearts. These changes may indicate a persistence of or reversion to earlier fetal patterns of gene $\tilde{\sigma}$ expression and are comparable with those observed $N$ for the cardiac myosin gene during development and $N$ in diseased human hearts. ${ }^{30-32}$ On the other hand, the ${ }_{\sigma}^{\omega}$ appearance of protein gene product 9.5 immunoreactivity in the ventricular conduction system is a novel $\stackrel{\circ}{=}$ finding that seems to have no fetal counterpart. It is of interest that a glycolytic isoenzyme, neurone? specific enolase, that is found in high concentration in $\frac{0}{0}$ the nervous and neuroendocrine systems has also 
been detected in the adult human conduction system. ${ }^{33}$ The functional significance of the occurrence of two distinct, so-called neuroendocrine marker proteins $^{34}$ in this tissue is not clear, but the localised distribution pattern of the immunostaining indicates a specific association with ventricular conduction cells containing natriuretic peptide, that is not seen in normal atrial and ventricular myocardium.

The localisation of immunoreactivity for atrial natriuretic peptide in the human ventricular conduction system extends earlier observations in the rat ${ }^{13-15}$ and pig heart ${ }^{16}$ and indicates that expression of the natriuretic peptide gene may be a general feature of the mammalian conduction system. A differential distribution of immunoreactivity was seen in the human fetal heart at mid-gestation and in the explanted adult heart at transplantation, with immunoreactivity being present in conduction cells rather than in the atrioventricular node or ventricular myocardium. This pattern of immunostaining is consistent with the view that conducting fibres have a separate origin from the atrioventricular node and ventricular myocytes. ${ }^{35}$ Circulating concentrations of atrial natriuretic peptide immunoreactivity are highest in the coronary sinus. This has also been shown to be the main site of venous drainage from the interventricular septum and conduction tissues. ${ }^{36}{ }^{37}$ While it is possible that in the failing or hypertrophic heart the ventricular production and release of the peptide makes an important contribution to circulating concentrations, it seems doubtful whether the conduction system could have an endocrine role like that proposed for the atria. We do not know whether the atrial natriuretic peptide inflences impulse conduction in the heart, but its release does appear to be modulated by changes in atrial ${ }^{18} 198$ and ventricular rhythm. ${ }^{39}$ In addition to serving a hormonal function, the peptide could also act locally to influence the contractility of the ventricular myocardium. ${ }^{10}$

We found atrial natriuretic peptide immunoreactivity in the human ventricular conduction system and myocardium as well as in atrial tissues. This raises the question of whether the natriuretic peptide should be described as "atrial" or "cardiac". Production of the peptide within the ventricles depends on the stage of development. In the diseased heart there seems to be persistence of or reversion to patterns of atrial natriuretic peptide gene expression seen in earlier fetal life.

Antisera to human $\alpha$-atrial natriuretic peptide and cardiodilatin sequences were produced in conjunction with Professor S R Bloom. We thank Mrs P Harley for technical assistance. This work was supported by the British Heart Foundation.

\section{References}

1 Cantin M, Gutkowska J, Thibault G, et al. Immunocytochemical localization of atrial natriuretic factor in the heart and salivary glands. Histochemistry 1984;80:113-27.

2 Maldonado CA, Saggau W, Forssmann WG. Cardiodilatin-immunoreactivity in specific atrial granules of human heart revealed by the immunogold stain. Anat Embryol (Berl) 1986;173:295-8.

3 Anderson JV, Christofides JC, Vinas P, et al. Radioimmunoassay of alpha rat atrial natriuretic peptide. Neuropeptides 1986;7:159-74.

4 Wharton J, Gulbenkian S. Peptides in the mammalian cardiovascular system. Experientia 1987;43:821-32.

5 Hassall CJS, Wharton J, Gulbenkian S, et al. Ventricular and atrial myocytes of newborn rats synthesise and secrete atrial natriuretic peptide in culture: light and electron-microscopical localisation and chromatographic examination of stored and secreted molecular forms. Cell Tissue Res 1988;251:161-9.

6 Gardner DG, Gertz BJ, Hane S. Thyroid hormone increases rat atrial natriuretic peptide messenger ribonucleic acid accumulation in vivo and in vitro. Mol Endocrinol 1987;1:260-5.

7 Bloch KD, Seidman JG, Naftilan JD, Fallon JT, Seidman CE. Neonatal atria and ventricles secrete atrial natriuretic factor via tissue-specific secretory pathways. Cell 1986;47:695-702.

8 Nemer M, Lavigne J-P, Drouin J, Thibault G, Gannon $M$, Antakly $T$. Expression of atrial natriuretic factor gene in heart ventricular tissue. Peptides (Fayetteville) 1986;7:1147-52.

9 Hamid Q, Wharton J, Terenghi G, et al. Localisation of atrial natriuretic peptide $\mathrm{mRNA}$ and immunoreactivity in the rat heart and human atrial appendage. Proc Natl Acad Sci USA 1987;84:6760-4.

10 Cantin M, Ding J, Thibault G, et al. Immunoreactive atrial natriuretic factor is present in both atria and ventricles. Mol Cell Endocrinol 1987;52:105-13.

11 Wei Y, Rodi CP, Day ML, et al. Developmental changes in the rat atriopeptin hormonal system. $J$ Clin Invest 1987;79:1325-9.

12 Kikuchi K, Nakao K, Hayashi K, et al. Ontogeny of atrial natriuretic polypeptide in the human heart. Acta Endocrinol (Copenh) 1987;115:211-7.

13 Thompson RP, Simson JAV, Currie MG. Atriopeptin distribution in the developing rat heart. Anat Embryol (Berl) 1986;175:227-33.

14 Back J, Stumpf WE, Ando E, Nokihara K, Forssmann WG. Immunocytochemical evidence for CDD/ANPlike peptides in strands of myoendocrine cells associated with the ventricular conduction system of the rat heart. Anat Embryol (Berl) 1986;175:223-6.

15 Scott JN, Jennes L. Distribution of atrial natriuretic factor in fetal rat atria and ventricles. Cell Tissue Res 1987;248:479-81.

16 Toshimori H, Toshimori K, Oura C, Matsuo H. Immunohistochemistry and immunocytochemistry of atrial natriuretic polypeptide in porcine heart. Histochemistry 1987;86:595-601.

17 Saito $Y$, Nakao K, Arai H, et al. Atrial natriuretic polypeptide (ANP) in human ventricle. Increased 
gene expression of ANP in dilated cardiomyopathy. Biochem Biophys Res Commun 1987;148:211-7.

18 Tikkanen I, Fyhrquist F, Metsärinne K, Leidenius R. Plasma atrial natriuretic peptide in cardiac disease and during infusion in healthy volunteers. Lancet 1985;ii:66-9.

19 Richards AM, Cleland JGF, Tonoto G, et al. Plasma $\alpha-$ natriuretic peptide in cardiac impairment. $\mathrm{Br}$ Med $J$ 1986;293:409-12.

20 Hara H, Ogihara T, Shima J, et al. Plasma atrial natriuretic peptide level as an index for the severity of congestive heart failure. Clin Cardiol 1987;10:437-42.

21. Tsuchimochi H, Yazaki Y, Ohno H, Takanashi R-I, Takaku $F$. Ventricular expression of atrial natriuretic peptide. Lancet 1987;i1:336-7.

22 Gulbenkian S, Wharton J, Polak JM. The visualisation of cardiovascular innervation in the guinea pig using an antiserum to protein gene product (PGP 9.5). $J$ Auton Nerv Syst 1987;18:235-47.

23 Meleagros L, Ghatei MA, Anderson JV, et al. The presence and molecular forms of cardiodilatin immunoreactivity in the human and rat right atrium. Clin Chim Acta 1988;172:199-210.

24 Smith A, Ho SY, Anderson RH. Histological study of the cardiac conducting system as a routine procedure. Med Lab Sci 1987;34:223-9.

25 Matsubara H, Hirata Y, Yoshimi H, et al. Ventricular myocytes from neonatal rats are more responsive to dexamethasone than atrial myocytes in synthesis of atrial antriuretic peptide. Biochem Biophys Res Commun 1987;148:1030-8.

26 Vassall-Adams PR. Ultrastructure of the human atrioventricular conduction tissues. Eur Heart J 1983;4:449-60.

27 Ding J, Thibault G, Gutkowska J, et al. Cardiac and plasma atrial natriuretic factor in experimental congestive heart failure. Endocrinology 1987;121:248-57.

28 Lattion A-L, Michel JB, Arnauld E, Corvol P, Soubrier F. Myocardial recruitment during ANF mRNA increase with volume overload in the rat. $A m J$ Physiol 1986;251:H890-6.

29 Day ML, Schwartz D, Wiegand RC, et al. Ventricular atriopeptin. Unmasking of messenger RNA and pep- tide synthesis by hypertrophy or dexamethasonec: Hypertension 1987;9:485-91.

30 Schwartz K, Mercadier J-J. Isomyosin shifts in normall and induced cardiac growth. In: Legato $\mathrm{MJ}$, ed. The developing heart. Boston: Martinus: Nijhoff, 1984음 149-71.

31 Bouvagnet $P$, Neveu S, Montoya M, Leger JJ. Develop $\mathbb{D}$ mental changes in the human cardiac isomyosin distribution: an immunohistochemical study using monoclonal antibodies. Circ Res 1987;61:329-36.

32 Kuro-o M, Tsuchimochi H, Ueda S, Takaku F, Yazaki $Y$. Distribution of cardiac myosin isozymes in human conduction system. Imimunohistochemistry study? using monoclonal antibodies. J Clin Invest 1986 $\frac{2}{2}$ 77:340-7.

33 Haimoto $\mathbf{H}$, Takahashi $Y$, Koshikawa T, Nagura $H_{+}$ Kato K. Immunohistochemical localisation of $\gamma^{+}$ enolase in normal human tissues other than nervous and neuroendocrine tissues. Lab Invest 1985;52. 257-63.

34 Thompson RJ, Doran JF, Jackson P, Dhillon AP, Rode J. PGP 9.5-a new marker for vertebrate neurons an neuroendocrine cells. Brain Res 1983;278:224-8.

35 Forsgren $S$. The differentiation of the purkinje fibres ind the mammalian heart-comparisons with the ordinary myocytes. In: Legato MJ, ed. The developing heart $ळ$ Boston: Martinus Nijhoff, 1984:47-67.

36 Hood WB Jr. Regional venous drainage of the human heart. Br Heart J 1968;30:105-9.

37 Eliška $O$, Elišková $M$. Venous circulation of the humañ cardiac conduction system. Br Heart J 1979;42O 508-13.

38 Roy D, Pillard F, Cassidy D, et al. Atrial natriureti® factor during atrial fibrillation and supraventricula tachycardia. J Am Coll Cardiol 1987;9:509-14.

39 Crozier IG, Nicholls MG, Ikram H, Espiner EA. Atriab natriuretic peptide in spontaneous tachycardiof [Abstract]. Br Heart J 1988;59:128.

40 Cramb G, Banks R, Rugg EL, Aiton JF. Actions of atrial natriuretic peptide (ANP) on cyclic nucleotide concentrations and phosphatidylinositol turnover in ventricular myocytes. Biochem Biophys Res Commuz 1987;148:962-70. 